\title{
Geochemical Modelling Data of Groundwater in the O'Kiep, Namaqualand Region, South Africa - 2013 to 2019: A Case of Evidenced Contamination by Historical Mining Activity
}

\author{
I.G. Erdogan ${ }^{\mathrm{a}, \mathrm{b}}$, K. Netshiongolwe ${ }^{\mathrm{c}}$, A. Mosai ${ }^{\mathrm{c}}$, E. Fosso-Kankeu ${ }^{\mathrm{a}}$, S.K.O, Ntwampe ${ }^{\mathrm{a}}$, F.B. Waanders ${ }^{\mathrm{a}}$ \\ and N. Hoth ${ }^{\mathrm{d}}$
}

\begin{abstract}
The integration of hydrogeochemical characteristics techniques and geochemical modelling were used to identify the significant factors governing groundwater hydrogeochemical evolution in the Namaqualand. The groundwater was classified into four sets namely: $\mathrm{Ca}-\mathrm{Mg}-\mathrm{HCO}_{3}, \mathrm{Na}-\mathrm{K}-\mathrm{HCO}_{3}, \mathrm{Na}-\mathrm{K}-\mathrm{Cl}-\mathrm{SO}_{4}$, and $\mathrm{Ca}-\mathrm{Mg}-\mathrm{Cl}-\mathrm{SO}_{4}$ between the periods of 2013 and 2019. The geochemical model PHREEQC suggests some geochemical reactions and mineral phases being responsible for the evolution of the groundwater chemistry and indicating that the groundwater hydrogeochemical evolution is mainly controlled by carbonate mineral dissolutions, cation exchange, precipitation and weathering. The increase in $\mathrm{SO}_{4}{ }^{-}$concentration in the period of 2019 in groundwater was most likely due to sulfide-mineral oxidation. The contributions of anthropogenic sources were associated with the closed metalliferous mine, metalliferous solid waste, and acid rock drainage; it is predicted that the risk of potentially toxic elements in the study area will probably increase in groundwater in a long-term. The accumulation of $\mathrm{SO}_{4}{ }^{-}$in the groundwater maybe due to the arid climate of the area. The groundwater of O'Kiep has been exposed to the progressive deterioration of water quality, with particularly significant increases in $\mathrm{Na}, \mathrm{Cl}$ and $\mathrm{SO}_{4}$. This information would contribute to risk assessments and evaluation of remediation strategies. It is therefore anticipated that the groundwater contamination will continue to persist in the study area for many years if the mitigative strategies are not implemented.
\end{abstract}

Keywords - Arid region, closed metalliferous mine, groundwater evolution, O'Kiep, PHREEQC

\section{INTRODUCTION}

Surface water is inadequate to meet the demand of drinking water in O'Kiep, due to the accumulative water demand by the

Manuscript received October 01, 2020. This work was supported in part by the North-West University, Cape Peninsula University of Technology (University Research Grant No.: RY12) and National Research Foundation (Thuthuka 2019: TTK180409318662).

${ }^{\mathrm{a}}$ Water Pollution Monitoring and Remediation Initiatives Research Group in the School of Chemical and Minerals Engineering at the North-West University, South Africa

b Department of Chemical Engineering, Cape Peninsula University of Technology, Cape Town South Africa

${ }^{\mathrm{c}}$ Molecular Sciences Institute, School of Chemistry, University of the Witwatersrand, Private Bag X3, Wits 2050, South Africa

${ }^{\mathrm{d}}$ Institute of Mining and Special Civil Engineering, Technische Universität Bergakademie Freiberg, Saxony, German. increasing populace and urbanisation. On the other hand, it is unsafe to rely on the drinking water supply system (DWSS) in O'Kiep due to the possible bacterial contamination and regular interruptions in this area [1]. Furthermore, earlier studies suggest that potential acid rock drainage (ARD) formation is recognised as one of the environmental challenges associated with groundwater contamination in this former mining area as highlighted in [2]. Since groundwater is an essential resource for the community of O'Kiep, and could possibly be used in the near future for drinking and irrigation purposes, it's monitoring is essential. Subsequently, some studies have been conducted in this area to determine the groundwater quality and its suitability for drinking and irrigation as discussed in [2], [3]. Although, soil acts as a natural filter, which removes and adsorbs the potentially toxic elements (PTEs), long-term release of ARD leads to the saturation of PTEs in the soil, with subsequent leachates sipping into the water table. Hence, it can also result in the reduction of filtration and adsorption capability of the soil and subsequently lead to deterioration of groundwater quality over time. Among many diverse contaminants, the presence of PTEs in groundwater is of major concern. Additionally, it has been reported that the ARD leaches into groundwater in O'Kiep. Overall, groundwater quality is influenced by the industrial activities, geology and climate conditions of an area. Furthermore, groundwater quality could be influenced by geochemical reactions such as dissolution, ion exchange, oxidation, precipitation in the aquifer whereby the groundwater is sourced [4], [5]. One of the tools that are normally used in hydrogeochemistry are the trilinear piper [6] and the Durov diagrams which evaluates the groundwater evolution while the latter reveals geochemical processes that could influence the groundwater genesis [4]. Hence, this part of the study aimed at determining the hydrogeochemical processes controlling the hydrogeochemical chemistry of the groundwater in O'Kiep and its evolution over time.

\section{MATERIALS AND METHODS}

\section{A. Hydrogeochemical parameters}

To determine the hydrogeochemical parameters of groundwater in O'Kiep, samples were collected from eight boreholes in the previous study of Erdogan, et al. [3], while 
historical data were extracted from a study published by Abiye and Leshomo [7]. Most of the boreholes in the study area are associated with a fractured basement aquifer in the Namaqualand. The Namaqualand is situated in the South-Western region of South Africa, an arid region of the Northern Cape [8]. The method used for measurement of hydrogeochemical parameters such as $\mathrm{pH}$, electrical conductivity (EC), total dissolved solids (TDS) and ions are as described in the study of Abiye and Leshomo [7] for 2013 period and Erdogan, et al. [3] for 2019 period. These hydrogeochemical parameters were compared to drinking water quality guidelines as described by SANS241-1 [9] and WHO [10].

\section{B. Geochemical modelling}

PHREEQC v3, a computer program written in the $\mathrm{C}++$ programming and developed by the US Geological Survey agency (https://www.usgs.gov/software/phreeqc-version-3), was used to perform an aqueous geochemical modelling that has capabilities to determine a saturation index (SI) and speciation determinations in a batch-type-reaction system [11], [12]. The interaction between the groundwater and rock mineralogy controls the geochemistry of the groundwater in specified study area [13]. Therefore, such an interaction was accounted for.

\section{Groundwater classification using trilinear piper and Durov diagrams}

To identify the different groundwater types for the area, the results of hydrogeochemical analyses were plotted on a trilinear piper diagram as presented in Fig. 1. The major ion concentrations of the groundwater data in the study area for the periods 2013 and 2019 were plotted on the confirmatory Durov diagram [14] as presented in Fig. 1b. Durov diagram improves the interpretation of the groundwater evolution and provides more information on the hydrogeochemical processes occurring in groundwater schemes such that it is easy to identify mixing of different water types, ion-exchange and reverse ion-exchange processes [15].

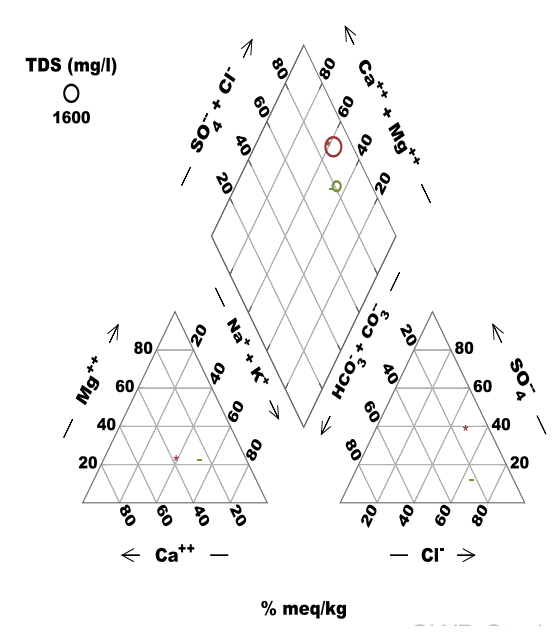

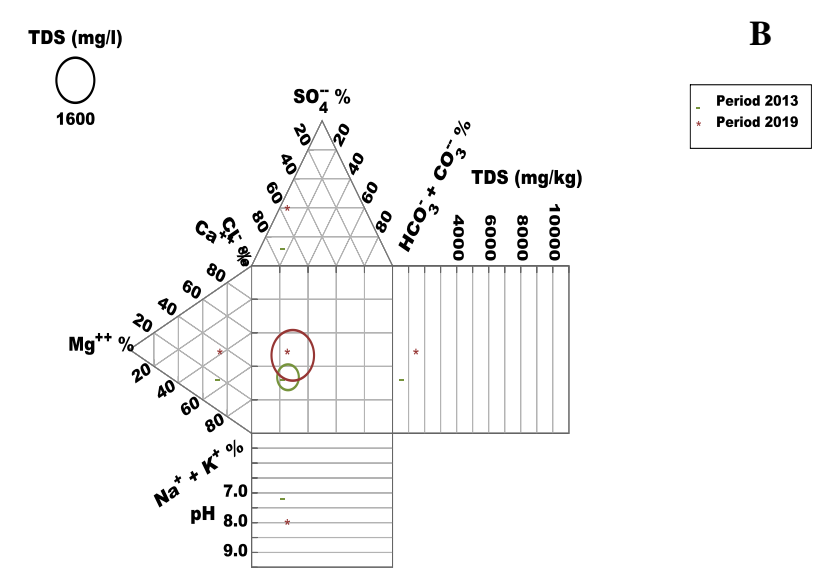

Fig. 1. Trilinear piper and Durov diagrams of the hydrogeochemical facies for groundwater classification.

\section{RESULTS AND DISCUSSION}

\section{A. Hydrogeochemical characteristics}

The high concentration values of standard deviation for these parameters display a high dispersion. This suggests that the groundwater hydrogeochemical characteristics showed a comprehensive spatial variation. The $\mathrm{pH}$ varied from 7.11 to 8.1 , indicating that the groundwater was slightly alkaline, which was attributed to mineral sources such as carbonates in the groundwater [16]. The EC and TDS values of groundwater increased from 2.04 to $241 \mathrm{mS} / \mathrm{cm}$ and from 911 to $1793 \mathrm{mg} / \mathrm{L}$, respectively. Additionally, the higher value of the standard deviation for EC (217 mS/cm) and TDS (1561 mg/L) suggests a great variability in the hydrogeochemical processes, which could be attributed to groundwater residence time, the heterogeneity of the nearby alluvial and crystalline basement of the aquifer [17] lithology and former mining activities especially in O'Kiep. In general, the abundant cations in groundwater were $\mathrm{Ca}, \mathrm{Mg}$ and $\mathrm{Na}$ [16]. The concentration of $\mathrm{Ca}, \mathrm{Mg}$, and $\mathrm{Na}$ changed from 78.5 to $184 \mathrm{mg} / \mathrm{L}$, from 51.5 to $67.3 \mathrm{mg} / \mathrm{L}$ and from 224 to $243 \mathrm{mg} / \mathrm{L}$, respectively.

Carbonate dissolution is the key source of $\mathrm{Ca}$ and alkalinity in groundwater. With respect to anions, $\mathrm{Cl}$ dominated in the groundwater samples and the concentration changed from 447 to $470 \mathrm{mg} / \mathrm{L}$ followed by $\mathrm{SO}_{4}$ from 121 to $455 \mathrm{mg} / \mathrm{L}$. An increase of $\mathrm{SO}_{4}$ with the increased in $\mathrm{Cl}$ could be due to the dissolution of soluble constituents such as halite and gypsum and halite as reported in [2]. On the other hand, the $\mathrm{NO}_{3}$ and $\mathrm{PO}_{4}$ decreased from 27.3 to $2.16 \mathrm{mg} / \mathrm{L}$ and from 1.41 to $0.5 \mathrm{mg} / \mathrm{L}$, respectively. It was observed that most of the parameters including $\mathrm{EC}$, TDS, $\mathrm{Na}$ and $\mathrm{Cl}$ were much higher than those obtained by [9] and [10].

\section{B. Groundwater classification}

The groundwater data for the periods 2013 and 2019 were described as chlorine type water, alkali and strong acid predominated and saline groundwater [16], [18]. The Namaqualand district is characterized by $\mathrm{Na}-\mathrm{Cl}$ region and 
widespread salt pans, which have significant role in governing the quality of groundwater salinity including increases, results which are similar to those obtained by Abiye, et al. [19]. The trilinear piper diagram presents the hydrogeochemical evolution of the groundwater during the studied period in the Namaqualand and substantiates the alterations amongst the four sets, namely: $\left(\mathrm{Ca}-\mathrm{Mg}-\mathrm{HCO}_{3}\right),\left(\mathrm{Na}-\mathrm{K}-\mathrm{HCO}_{3}\right),(\mathrm{Na}-\mathrm{K}-$ $\left.\mathrm{Cl}-\mathrm{SO}_{4}\right)$, and $\left(\mathrm{Ca}-\mathrm{Mg}-\mathrm{Cl}-\mathrm{SO}_{4}\right)$ types for both periods (2013 and 2019), (Fig. 1a). The groundwater evolved from low mineralized with EC of $2.04 \mathrm{mS} / \mathrm{cm}$ for 2013 period to progressive increase in salinity with EC of $241 \mathrm{mS} / \mathrm{cm}$ for 2019 period. Groundwater rich in $\mathrm{Na}$ and $\mathrm{K}$ represents $80 \%$ for both period 2013 and 2019. This was confirmed by the Durov diagram Fig. 1b, where the majority of groundwater were in ion exchange zone for the periods 2013 and 2019; while $\mathrm{Ca}$ was $21 \%$ for the period 2013 and 39\% for 2019 period. However, groundwater dominant in $\mathrm{Cl}_{-} \mathrm{SO}_{4}$, producing a chlorine groundwater type represents $80 \%$ for the period of 2013 and 90\% for 2019 period. Additionally, the Durov diagram shows that $\mathrm{Cl}$ ion is the main ion responsible for the increased salinity, even though the $\mathrm{SO}_{4}$ ion is also significant in 2019. According to Leshomo [20] and as highlighted in the study by Erdogan, et al. [3], the salinity in the groundwater of Namaqualand is derived from halite dissolution and seawater mixing. For alkaline water with predominant $\mathrm{Na}-\mathrm{K}-\mathrm{Cl}-\mathrm{SO}_{4}$, as strong acids $\left(\mathrm{Cl}\right.$ and $\left.\mathrm{SO}_{4}\right)$, facies represent $90 \%$ for 2019 period. In general, ion-exchange process and weathering of rocks are mainly governing the groundwater hydrogeochemistry of Namaqualand. The data plots in trilinear piper diagram and Durov diagram revealed that cations were dominated by $\mathrm{Na}$ and $\mathrm{K}$ followed by $\mathrm{Ca}$ and $\mathrm{Mg}$, while anions were dominated by $\mathrm{Cl}$ and $\mathrm{SO}_{4}$ (Fig. 1b). The increased in $\mathrm{SO}_{4}$ concentrations in 2019 period were hypothesized to originate from historical mining-associated activities due sulfide-mineral oxidation in the SMW and MTs [21].

\section{Geochemical modelling}

In this part of the study, inverse geochemical model for the observed variations from the period 2013 to the period 2019 was performed, given that it is characteristic of groundwater hydrogeochemical evolution in the Namaqualand. A PHREEQC modelling software approach allows for the simulation and characterization of the hydrogeochemical processes influencing surface and groundwater qualities $[22,23]$. The composition of the groundwater contaminated by various PTEs can be used to predict reactive mineral mechanisms. Any variations observed between different datasets can determine the geological matrix interaction between significant anions and cations [24]. As PHREEQC determines the saturation index (SI) of various minerals in numerous mixtures and solutions; therefore, a positive SI indicates precipitation or supersaturation of secondary minerals and a negative SI indicates the dissolution or undersaturation of minerals; while an SI of \pm 0.5 indicates equilibrium conditions [25]. Fig. 2 represents the changes of the SI of particular phases.

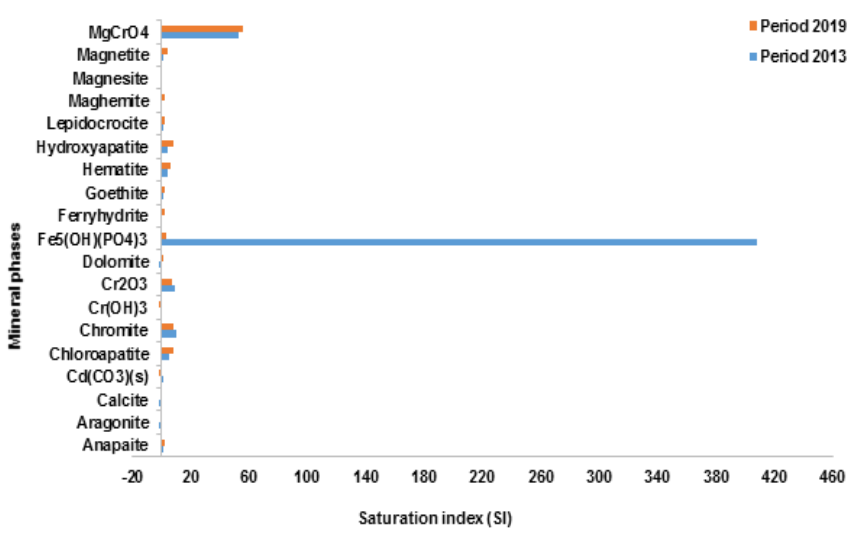

Fig. 2. Saturation index of mineral phases in Namaqualand for 2013 and 2019 period.

The model output showed phases that are governing the groundwater chemistry in the region, with some geochemical reactions being shown to be responsible for the evolution of the groundwater chemistry whereby the dissolution of the carbonate minerals such as aragonite, $\mathrm{Ca}_{3}\left(\mathrm{PO}_{4}\right)_{2}$, calcite dolomite, ferrihydrite and vaterite were identified as initially undersaturated (2013) to supersaturated (2019) with an undersaturation of $\mathrm{Cd}\left(\mathrm{CO}_{3}\right), \mathrm{Cr}(\mathrm{OH})_{3}$ being observed during the same period. Similarly, the precipitation of anapaite, chloroapatite, chromite, $\mathrm{Cr}_{2} \mathrm{O}_{3} \mathrm{Fe}_{5}(\mathrm{OH})\left(\mathrm{PO}_{4}\right)_{3}$, ferryhydrite, goethite, hematite, hydroxyapatite, lepidocrocite, maghemite, magnetite was observed, with magnesite evolving from being undersaturated to an equilibrium phase. Gypsum, siderite and halite remained undersaturated, indicating that these minerals may be subjected to continuous dissolution as the groundwater hydrogeochemical evolution is mainly controlled by carbonate mineral dissolutions, cation exchange, precipitation and weathering.

\section{CONCLUSION}

In this research, the integration of hydrogeochemical characteristics techniques and geochemical modelling were used to identify the significant factors governing groundwater hydrogeochemical evolution in Namaqualand. The $\mathrm{pH}$ values of the groundwater were alkaline in nature during 2013 and 2019 period. Most of the parameters including EC, TDS, Na and $\mathrm{Cl}$ exceeded permissible limits of drinking water standards stipulated by the SANS241-1 [9] and WHO [10]; standards for drinking water. $\mathrm{Ca}-\mathrm{Mg}-\mathrm{HCO}_{3}, \mathrm{Na}-\mathrm{K}-\mathrm{HCO}_{3}, \mathrm{Na}-\mathrm{K}-\mathrm{Cl}-\mathrm{SO}_{4}$, and $\mathrm{Ca}-\mathrm{Mg}-\mathrm{Cl}-\mathrm{SO}_{4}$ types for both periods (2013 and 2019). The geochemical model PHREEQC suggests some geochemical reactions and mineral phases being responsible for the evolution of the groundwater chemistry and indicating that the groundwater hydrogeochemical evolution is mainly controlled by carbonate mineral dissolutions, cation exchange, precipitation and weathering. The increase in sulfate concentration in period 2019 in groundwater was most likely due to sulfide-mineral oxidation. The contributions of anthropogenic sources were associated with the closed 
metalliferous waste, metalliferous waste and acid rock drainage, it is predicted that the risk of PTEs contamination in the study area will probably contribute to groundwater quality degradation. The accumulation of $\mathrm{SO}_{4}$ in the groundwater maybe due to the arid climate of the area. The typical hypothesis applied at numerous mining locations is that sulfide-mineral oxidation is the main source of sulfate. This information would contribute to risk assessments and evaluation of remediation strategies. It is therefore anticipated that the groundwater contamination will continue to persist in the study area for many years.

\section{ACKNOWLEDGMENT}

Author EFK acknowledged the financial support from the National Research Foundation (NRF) in South Africa (Grant No: 120323); Any opinion, findings and conclusions or recommendations expressed in this material are those of the authors and therefore the NRF does not accept any liability in regard thereto.

\section{REFERENCES}

[1] I. Erdogan, E. Fosso-Kankeu, F. Waanders, S. Ntwampe, and N. Hoth, "Households water quality in O'Kiep-South Africa and community perception of related health risks," Desalination and Water Treatment no. 167, pp. 145-155, 2019. https://doi.org/10.5004/dwt.2019.24576

[2] I. Erdogan, E. Fosso-Kankeu, S. Ntwampe, F. Waanders, and N. Hoth, "Seasonal variation of hydrochemical characteristics of open-pit groundwater near a closed metalliferous mine in O'Kiep, Namaqualand Region, South Africa," Environmental Earth Sciences, vol. 79, no. 5, pp. $1-15,2020$. https://doi.org/10.1007/s12665-020-8863-2

[3] I. Erdogan, E. Fosso-Kankeu, S. Ntwampe, F. Waanders, N. Hoth, and A. Rand, "Groundwater as an alternative source to irregular surface water in the O'Kiep area, Namaqualand, South Africa," Physics and Chemistry of the Earth, vol. 114, A/B/C, pp. 102801, 2019. https://doi.org/10.1016/j.pce.2019.09.003

[4] P. Ravikumar, R. Somashekar, and K. Prakash, "A comparative study on usage of Durov and Piper diagrams to interpret hydrochemical processes in groundwater from SRLIS river basin, Karnataka, India," Elixir International Journal, vol. 80, pp. 31073-31077, 2015.

[5] G. Sakram, R. Sundaraiah, and P. R. S. Vishnu Bhoopathi, "The impact of agricultural activity on the chemical quality of groundwater, Karanja Vagu Watershed, Medak District, Andhra Pradesh," International Journal of Advanced Technology and Science Research, vol. 6, no. 3, pp. 769-786, 2013.

[6] A. Piper, "A graphic representation in the geochemical interpretation of groundwater analyses," Transactions of the American Geophysical Union, vol. 25, pp. 914-923, 1953. https://doi.org/10.1029/TR025i006p00914

[7] T. A. Abiye and J. T. Leshomo, "Groundwater flow and radioactivity in Namaqualand, South Africa," Environmental Earth Sciences, vol. 70, no. 1, pp. 281-293, 2013. https://doi.org/10.1007/s12665-012-2126-9

[8] M. Brenzinger, "The twelve modern Khoisan languages," in Khoisan languages and linguistics: Proceedings of the 3rd International Symposium, Riezlern/Kleinwalsertal, Jul 6 2008, pp. 1-31.

[9] SANS241-1, "South African National Standard: Drinking water. Part 1. Microbial, physical, aesthetic and chemical determinants," 2 ed. Pretoria: SABS 2015.

[10] WHO, "Guidelines for drinking-water quality," ed. Geneva: World Health Organisation, 2011.

[11] D. L. Parkhurst and C. Appelo, "Description of input and examples for PHREEQC version 3: A computer program for speciation, batch-reaction, one-dimensional transport, and inverse geochemical calculations," US Geological Survey, 2328-7055, 2013. [Online]. Available: https://pubs.er.usgs.gov/publication/tm6A43
[12] D. L. Parkhurst and C. Appelo, "User's guide to PHREEQC (Version 2): A computer program for speciation, batch-reaction, one-dimensional transport, and inverse geochemical calculations," in "Water-resources investigations report," U.S. Department of Interior, Denver, Colorado, 99-4259, 1999, vol. 99. [Online]. Available: http://acamedia.info/sciences/J_G/references/PHREEQC_Manual.pdf

[13] A. Kumar, S. S. Roy, and C. K. Singh, "Geochemistry and associated human health risk through potential harmful elements (PHEs) in groundwater of the Indus basin, India," Environmental Earth Sciences, vol. 79, no. 4, pp. 86, 2020. https://doi.org/10.1007/s12665-020-8818-7

[14] S. Durov, "Natural waters and graphic representation of their composition," Dokl Akad Nauk SSSR, vol. 59, no. 3, pp. 87-90, 1948.

[15] A. A. Aly, A. M. Al-Omran, and M. M. Alharby, "The water quality index and hydrochemical characterization of groundwater resources in Hafar Albatin, Saudi Arabia," Arabian Journal of Geosciences, vol. 8, no. 6, pp. 4177-4190, 2015

https://doi.org/10.1007/s12517-014-1463-2

[16] F. Liu, S. Wang, T. C. J. Yeh, P. Zhen, L. Wang, and L. Shi, "Using multivariate statistical techniques and geochemical modelling to identify factors controlling the evolution of groundwater chemistry in a typical transitional area between Taihang Mountains and North China Plain," Hydrological Processes, vol. 34, no. 8, pp. 1888-1905, 2020 https://doi.org/10.1002/hyp.13701.

[17] R. Titus, S. Adams, and Y. Xu, "Groundwater Situation Assessment in Olifants Doorn Water Management Area (Version 1)," Final draft report prepared for Danced Project of Department of Water Affairs and Forestry. Groundwater Group, Department of Earth Sciences at the University of the Western Cape, Bellville, 2002. [Online]. Avalable: http://www.wrc.org.za/wp-content/uploads/mdocs/TT299-07.pdf

[18] P. Ravikumar and R. Somashekar, "Principal component analysis and hydrochemical facies characterization to evaluate groundwater quality in Varahi river basin, Karnataka state, India," Applied Water Science, vol. 7, no. 2, pp. 745-755, 2017. https://doi.org/10.1007/s13201-015-0287-x

[19] T. Abiye, G. Bybee, and J. Leshomo, "Fluoride concentrations in the arid Namaqualand and the Waterberg groundwater, South Africa: Understanding the controls of mobilization through hydrogeochemical and environmental isotopic approaches," Groundwater for Sustainable Development, vol. 6, pp. 112-120, 2018. https://doi.org/10.1016/j.gsd.2017.12.004

[20] J. Leshomo, "Investigation of hydrochemistry and uranium radioactivity in the groundwater of Namaqualand, Northern Cape, South Africa," MSc Thesis, School of Geosciences, University of Witwatersrand, Johannesburg, South Africa, 2011.

[21] Z. Miao, K. C. Carroll, and M. L. Brusseau, "Characterization and quantification of groundwater sulfate sources at a mining site in an arid climate: The Monument Valley site in Arizona, USA," Journal of Hydrology, vol. 504, pp. 207-215, 2013. https://doi.org/10.1016/j.jhydrol.2013.09.030

[22] Elvis Fosso-Kankeu, Alusani Manyatshe, Frans Waanders. 2017. Mobility potential of metals in acid mine drainage occurring in the Highveld area of Mpumalanga Province in South Africa: Implication of sediments and efflorescent crusts. International Biodeterioration and Biodegradation. 119: 661-670. https://doi.org/10.1016/j.ibiod.2016.09.018

[23] Manyatshe A, Fosso-Kankeu E, van der Berg D, Lemmer N, Waanders F, Tutu H. 2018. Metal speciation in the rivers around Potchefstroom based on seasonality. Water Environment Research. 90(1): 84-95. https://doi.org/10.2175/106143017X15054988926587

[24] A. Maoui, N. Kherici, and F. Derradji, "Hydrochemistry of an Albian sandstone aquifer in a semi arid region, Ain oussera, Algeria," Environmental Earth Sciences, vol. 60, no. 4, pp. 689-701, 2010. https://doi.org/10.1007/s12665-009-0207-1

[25] S. Chidambaram, P. Anandhan, M. Prasanna, A. Ramanathan, K. Srinivasamoorthy, and G. S. Kumar, "Hydrogeochemical modelling for groundwater in Neyveli aquifer, Tamil Nadu, India, using PHREEQC: a case study," Natural Resources Research, vol. 21, no. 3, pp. 311-324, 2012

https://doi.org/10.1007/s11053-012-9180-6 